\title{
Studi Perencanaan Pembangkit Listrik Tenaga Sampah Pada TPA Sambutan Kota Samarinda
}

\author{
Thorikul Huda ${ }^{1}$, Anjelica Preccilia Amor ${ }^{2}$, Yun Tonce Kusuma Priyanto ${ }^{3}$ \\ ${ }^{1}$ Teknik Elektro, Jurusan Teknologi Industri dan Proses, ITK, Balikpapan. Email: thorikul.h@itk.ac.id \\ ${ }^{2}$ Teknik Elektro, Jurusan Teknologi Industri dan Proses, ITK, Balikpapan. Email: anjelicapreccilia@gmail.com \\ ${ }^{3}$ Teknik Elektro, Jurusan Teknologi Industri dan Proses, ITK, Balikpapan City. Email: yuntonce@itk.ac.id
}

\begin{abstract}
Nowadays, garbage has always been considered a problem that is commonly found in urban areas. In general, waste management only moves rubbish from a temporary shelter to a final processing site. The development of increasingly advanced technology provides alternative solutions for processing waste into an energy source. The application of waste processing technology is a renewable energy source, namely the Waste Power Plant. Samarinda City is a densely populated city that produces quite large waste. According to the final processing site record in 2017, the amount of waste collected is 7,519,494 tons/year and will continue to increase. Organic waste that is piled-up will undergo an anaerobic decomposition process so as to produce a gas called landfill gas which can be converted into electrical energy. In this study to calculate the potential of landfill gas, landfill gas will be converted into electrical energy using gas engine technology with the type of J320 GS janbacher which can produce electricity of 1,063kW. Landfill gas produced in Samarinda City's TPA reaches 684,693,866 $\mathrm{m}^{3}$ in 2019 and will increase every year until 2034 with electricity generated 2,822,107.61 $\mathrm{kWh}$ in 2019 and increasing up to the year 2034 and the investment cost for Waste Power Plant construction is Rp. 25,092,450,601 with investment evaluation analysis Net Present Value $(N P V)=17,539,868,600 I D R, I R R=19 \%, B C R=1,672$ and $P B=3,4$ Years. From the results of the evaluation, it was found that the Waste Power Plant in a final processing site planning in Samarinda City could meet the eligibility criteria to be built.
\end{abstract}

Keywords: electric energy, landfill gas, renewble energy, final processing site.

\begin{abstract}
Abstrak
Selama ini sampah selalu dianggap sebagai masalah yang lazim ditemukan pada wilayah perkotaan. Secara umum tata kelola sampah hanya memindahkan sampah dari tempat penampungan sementara (TPS) ke tempat pemrosesan akhir (TPA). Perkembangan teknologi yang semakin maju memberikan solusi alternatif pengolahan sampah menjadi sumber energi. Penerapan teknologi pengolahan sampah menjadi sumber energi terbarukan yaitu Pembangkit Listrik Tenaga Sampah (PLTSa). Kota Samarinda merupakan kota padat penduduk yang memproduksi sampah cukup besar. Menurut catatan TPA Sambutan pada tahun 2017 sampah yang terkumpul sebanyak 7.519,494 ton/tahun dan akan terus meningkat. Sampah organik yang ditimbun akan mengalami proses dekomposisi secara anaerobik sehingga menghasilkan gas yang disebut dengan gas landfill yang dapat di konversikan menjadi energi listrik. Pada penelitian ini untuk menghitung potensi gas landfill, Gas landfill akan dikonversi menjadi energy listrik menggunakan teknologi gas engine dengan tipe janbacher J320 GS yang dapat meghasilkan listrik sebesar 1.063kW. Gas landfill yang dihasilkan pada TPA Sambutan Kota Samarinda mencapai nilai 684.693,866 $\mathrm{m}^{3}$ pada tahun 2019 dan akan meningkat setiap tahunnya sampai dengan tahun 2034 dengan energi listrik yang dihasilkan 2.822.107,61 kWh pada tahun 2019 dan meningkat sampai dengan tahun 2034 dan Biaya investasi untuk pembangunan PLTSa yaitu sebesar Rp. 25.092.450.601 dengan analisis evaluasi investasi Net Present Value $(N P V)=R p .17 .539 .868 .600, I R R=19 \%, B C R=1,672$ dan $P B=3,4$ Tahun. Dari hasil evaluasi tersebut diperoleh bahwa perencanaan PLTSa TPA Sambutan di Kota Samarinda dapat memenuhi kriteria kelayakan untuk dibangun.
\end{abstract}

Kata Kunci: energi listrik, gas landfill, renewble energi, TPA.

\section{Pendahuluan}

Energi listrik merupakan suatu kebutuhan pokok dan selalu meningkat dari tahun ke tahun. Hampir semua aktivitas manusia memerlukan energi listrik. Keterbatasan tenaga listrik merupakan salah satu permasalahan yang harus segera diatasi sehingga tidak mengakibatkan krisis yang dapat berdampak 
lebih besar. Dalam hal penyediaan listrik, daerah-daerah terpencil dan pedesaan umumnya banyak yang belum terjangkau jaringan listrik PLN. Penggunaan pembangkit berbahan bakar fosil untuk daerah terpencil biasanya tidak ekonomis, karena skala pembangkitan yang terlalu kecil akan mengakibatkan tingginya biaya pokok produksi. Meskipun demikian, penyediaan listrik tetap harus dilakukan karena merupakan investasi sosial yang tak terhindarkan dalam rangka peningkatan kesejahteraan masyarakat.

Pemerintah memiliki program 35.000 MW yang terbagi menjadi pembangkit tenaga batubara $50 \%$, gas 25\% dan EBT 25\% (Jurnal Energi KESDM, 2016). Pemilihan pembangkit yang murah dan ramah lingkungan dengan menggunakan energi baru terbarukan seperti tenaga air, panas bumi, mini/mikrohidro, tenaga angin, tenaga surya, bahan bakar nabati, dan biomass.

Selama ini sampah selalu dianggap sebagai masalah yang lazim ditemukan pada wilayah perkotaan. Secara umum tata kelola sampah hanya memindahkan sampah dari tempat penampungan sementara (TPS) ke tempat pemrosesan akhir (TPA). Perkembangan teknologi yang semakin maju memberikan solusi alternatif pengolahan sampah menjadi sumber energi. Penerapan teknologi pengolahan sampah menjadi sumber energi terbarukan (renewable energi) membutuhkan perencanaan yang matang (Kuncoro, 2009).

Penelitian sebelumnya (Azarini, 2017), menyajikan tentang pengolahan sampah menjadi energi listrik pada TPA Putri Cempo dengan menggunakan metode insinerasi. Insinerasi adalah teknologi pengolahan sampah dengan cara dibakar pada temperatur lebih dari $800^{\circ} \mathrm{C}$. rata - rata energi yang dihasilkan dari pembakaran 1 ton sampah adalah $15 \mathrm{kWh}$. Metode insinerasi memiliki kekurangan yaitu dapat menimbulkan polusi udara akibat debu pembakaran yang dihasilkan dan membutuhkan lahan yang sangat luas yaitu $5 \mathrm{Ha}$.

Penelitian sebelumnya (Kuncoro, 2011), menyajikan Studi Pembangunan Pembangkit Listrik Tenaga Sampah 10 MW di Kota Medan dengan menggunakan teknologi landfill gas, dimana pemanfaatan gas metana $\left(\mathrm{CH}_{4}\right)$ yang diperoleh dari hasil dekomposisi sampah organik pada landfill area yang telah disediakan. Teknologi ini merupakan teknologi secara biologis dan tidak menggunakan mekanisme pembakaran.

Sampah organik yang ditimbun akan mengalami proses dekomposisi secara anaerobik sehingga menghasilkan gas yang disebut dengan gas landfill. Gas tersebut mengandung berbagai jenis senyawa seperti karbon dioksida dan gas metana (Terraza, 2010). Gas landfill yang terkumpul dari proses fermentasi anaerobik bahan organik tersebut akan menyebabkan meningkatnya suhu disekitar TPA, menimbulkan bau tidak sedap bahkan dapat memicu terjadinya ledakan. Namun, apabila gas metana yang terkandung pada gas landfill dikelola dengan baik, maka dapat memberikan berbagai keuntungan seperti mengurangi efek rumah kaca dan kerusakan lingkungan bahkan dapat dimanfaatkan sebagai bahan bakar pembangkit listrik yang disebut dengan pembangkit Listrik Tenaga Sampah (PLTSa).

Kota Samarinda digolongkan sebagai kota besar, dari jumlah penduduk dapat dihitung perkiraan timbulan sampah yang dihasilkan. Penduduk Kota Samarinda tercatat mencapai 812.597 jiwa (Badan Pusat Statistik Kota Samarinda, 2015). Menurut Badan Perencanaan Pembangunan Daerah (BAPPEDA) Kota Samarinda. Ketersediaan sumber alami seperti Sampah di Samarinda selama 4 (empat) tahun awal data 2009-2013 jumlah produksi sampah Kota Samarinda mengalami peningkatan paling besar di tahun 2012 yaitu sebanyak $995.449 \mathrm{~m}^{3}$, sangat memungkinkan untuk dijadikan sebagai sumber energi listrik.

Pembangkit listrik yang memanfaatkan gas landfill sebagai bahan bakar utama dinamakan dengan Pembangkit Listrik Tenaga Sampah (PLTSa) yang tergolong kedalam pembangkit energi listrik alternatif. Pemanfaatan dan pembangunan pembangkit listrik alternatif merupakan salah satu cara yang paling tepat untuk mencukupi kebutuhan energi listrik di Kota Samarinda. Oleh sebab itu, kajian terhadap potensi gas landfill dari TPA Sambutan Kota Samarinda sebagai bahan bakar utama Pembangkit Listrik Tenaga Sampah (PLTSa) perlu dilakukan dalam rangka mengatasi permasalahan ketersediaan energi. 
Pembangkit listrik merupakan suatu rangkaian alat yang mengubah energi gerak (mekanikal) yang kemudian dapat menghasilkan energi listrik, biasanya rangkaian alat terdiri dari turbin dan generator listrik. Dimana fungsi dari turbin sebagai alat untuk memutar rotor dari generator listrik, sehingga dari putaran rotor itu dhasilkan energi listrik. Sistem pembangkitan tenaga listrik yang mengubah energi alam menjadi mekanik selanjutnya menjadi energi listrik dapat dikatagorikan berdasarkan bahan bakar yang digunakannya. Ada beberapa pembangkit listrik, diantaranya Pembangkit Listrik Tenaga Air (PLTA), Pembangkit Listrik Tenaga Gas (PLTG), Pembangkit Listrik Tenaga Uap (PLTU), Pembangkit Listrik Tenaga Nuklir (PLTN), Pembangkit Listrik Tenaga Surya (PLTS), dan lain-lain.

Beberapa jenis pembangkit listrik diatas dibedakan atas dasar bahan baku yang digunakan untuk menggerakan generator maupun turbin. Oleh karena itu, setiap jenis pembangkit dinamakan berdasarkan jenis bahan baku yang digunakan baik bahan bakar fosil mupun energi terbarukan. Pembangkit Listrik Tenaga Sampah (PLTSa), sama halnya dengan pembangkit lainnya. Namun yang membedakan jenis pembangkit ini adalah dengan menggunakan gas. Dimana, gas berasal dari sampah yang mengalami penguraian secara alami dengan proses anaerobik. Gas ini merupakan gas yang secara alami dimiliki oleh setiap sampah dengan jenis organic. Sehingga pembangkit ini dinamakan pembangkit listrik tenaga sampah (Syarifudin,2012)

PLTSa ini adalah pembangkit yang menggunakan gas dari landfill hasil dekomposisi sampah, yang kemudian akan dimanfaatkan gas metana yang terkandung didalamnnya sebagai bahan bakar generator, yang kemudian akan menghasilkan listrik. Proses dalam pembangkitan gas landfill dimana, akan diolah yang sebelumnya melewati beberapa proses sebelum nantinya akan digunakan sebagai bahan baku pembangkit listrik. Gas yang dihasilkan oleh landfill (LFG) melalui proses anaerobik, kemudian gas ditangkap oleh sumur gas dan dibantu untuk dinaikkan ke permukaan dengan menggunakan blower. Selain gas, output yang dihasilkan dalam proses tersebut adalah air lindi (leachate). Dengan adanya lapisan geomembran didalam landfill, maka air lindi tidak akan mencemari tanah maupun air tanah yang kemudian air lindi dialirkan menuju tempat penampungan air lindi melalui pipa-pipa yang telah disediakan.

\section{Metode}

Tahap pelaksanaan penelitian ini meliputi studi literatur, pengumpulan data, tahap pengolahan data, menentukan kapasitas komponen-komponen PLTSa, dan analisa ekonomi PLTSa.

\section{Hasil dan Pembahasan}

\subsection{Data Jumlah Penduduk}

Pengambilan data jumlah penduduk kecamatan sambutan Kota Samarinda selama tahun 2010-2017 yang diperoleh melalui Badan Pusat Statistik Kota Samarinda. Untuk mengetahui jumlah gas metana yang dihasilkan TPA Sambutan setiap tahun, maka perlu dilakukan terlebih dahulu proyeksi laju pertumbuhan jumlah penduduk Kecamatan Sambutan, Kota Samarinda. Hal ini dikarenakan jumlah sampah yang diangkut dan tertimbun di TPA Sambutan setiap tahunnya tidak akan sama. Jumlah timbulan sampah kota akan berbanding lurus dengan populasi penduduk. Untuk memproyeksikan laju pertumbuhan jumlah penduduk digunakan persamaan sebagai berikut:

Tabel 1 Data Jumlah Penduduk

\begin{tabular}{ccc}
\hline Tahun & $\begin{array}{c}\text { Jumlah } \\
\text { Penduduk }\end{array}$ & r (\%) \\
\hline 2010 & 43.651 & - \\
2014 & 47.822 & 0,023077 \\
2015 & 48.756 & 0,019531 \\
2016 & 49.708 & 0,019526 \\
2017 & 50.678 & 0,019514 \\
\hline
\end{tabular}

3.2. Data Sampah TPA Sambutan

Pengambilan data jumlah sampah dengan satuan ton selama tahun 2015-2017 diperoleh melalui Dinas Lingkungan Hidup Kota Samarinda pada bulan Januari-Februari 2019. 
Tabel 2 Data Sampah TPA Sambutan, Kota Samarinda

\begin{tabular}{cccc}
\hline No & Tahun & $\begin{array}{c}\text { Massa Sampah } \\
\text { (Ton)/Hari }\end{array}$ & $\begin{array}{c}\text { Massa Sampah } \\
\text { (Ton)/Tahun }\end{array}$ \\
\hline 1 & 2015 & 297 & $2.603,717$ \\
2 & 2016 & 827,78 & $7.251,352$ \\
3 & 2017 & 858,39 & $7.519,494$ \\
\hline
\end{tabular}

\subsection{Data Jenis Sampah}

Untuk komposisi sampah di TPA Sambutan didapatkan dari asumsi bahwa komposisi timbulan sampah yang dihasilkan oleh Samarinda Utara serta kecamatan sekitarnya dengan yang diangkut ke TPA Sambutan bernilai sama.

Tabel 3 Komposisi Sampah Kota Samarinda

\begin{tabular}{|c|c|c|c|c|}
\hline No & $\begin{array}{l}\text { Penggolongan } \\
\text { Sampah }\end{array}$ & Jenis Sampah & Presentase $(\%)$ & Jumlah (\%) \\
\hline 1 & Mudah Terurai & $\begin{array}{c}\text { Organik } \\
\text { Sisa Makanan }\end{array}$ & $\begin{array}{c}38,3 \\
13,73\end{array}$ & 52,03 \\
\hline
\end{tabular}

\subsection{Potensi Gas Landfill}

Gas landfill atau LFG merupakan gas yang dihasilkan oleh mikroba pada saat bahan organik mengalami proses fermentasi dalam suatu keadaan anaerobik yang sesuai baik dari segi suhu, kelembaban, dan keasaman. Produksi gas dari sanitary landfill melalui proses anaerobik terdiri dari beberapa jenis dengan presentasi dan volume yang sangat bervariasi (Amelya, 2015), LFG dapat terjadi akibat penguraian material organik yang terdapat pada tempat pembuangan akhir. Sebagian besar kandungan dari gas landfill adalah metana dan karbon dioksida (Mannfredi dkk, 2009)

Tabel 4. Presentase gas penyusun LFG (Garcilasso , 2011)

\begin{tabular}{cccc}
\hline No & Gas Penyusun LFG & $\begin{array}{c}\text { Rumus } \\
\text { Kimia }\end{array}$ & $\begin{array}{c}\text { Presentase } \\
\text { Kandungan }\end{array}$ \\
\hline 1 & Metana & $\mathrm{CH}_{4}$ & $40-60 \%$ \\
2 & Karbon dioksida & $\mathrm{CO}_{2}$ & $25-50 \%$ \\
3 & Nitrogen & $\mathrm{N}_{2}$ & $3-15 \%$ \\
4 & Oksigen & $\mathrm{O}_{2}$ & $0-4 \%$ \\
5 & Hidrogen & $\mathrm{H}_{2}$ & $0-1 \%$ \\
6 & Argon & $\mathrm{Ar}$ & $0-4 \%$ \\
7 & Hydrogen sulfide & $\mathrm{H}_{2} S$ & $0-200 \mathrm{ppm}$ \\
8 & Clorine & $\mathrm{Cl}$ & $0-200 \mathrm{ppm}$ \\
9 & Fluerine & $\mathrm{F}$ & $0-200 \mathrm{ppm}$ \\
\hline
\end{tabular}

Tabel 4 memperlihatkan presentase gas penyusun LFG, terlihat bahwa kandungan gas terbesar yang terdapat pada LFG adalah metana sebesar $45-60 \%$ dan diikuti oleh karbon dioksida sebesar $25-50$ $\%$. Baik gas metana maupun karbon dioksida memiliki peran dalam peningkatan pemanasan suhu bumi dan dikategorikan sebagai gas rumah kaca (GRK). Landfill gas yang dihasilkan pada tempat pembuangan akhir akan berbahaya apabila tidak dikelola dan dikendalikan dengan baik. Kandungan gas metana pada LFG merupakan gas yang mudah terbakar sehingga resiko terjadi ledakan disekitar lokasi TPA sangat tinggi. Menurut Bernstein (2007), pengaruh gas metana terhadap peningkatan pemanasan global 21 kali lebih besar dibandingkan dengan karbon dioksida. Proses flaring dan ekstraksi gas metana dapat dilakukan sebagai upaya menurunkan emisi gas metan dan mengubahnya menjadi $\mathrm{CO}_{2}$.

\subsection{Estimasi Potensi Energi Listrik}

Perhitungan estimasi potensi energi listrik membutuhkan data gas metana yang dihasilkan seperti yang telah tertera pada table 6 dan juga dibutuhkan data konversi gas metana menjadi energi listrik yang tertera pada tabel 5 . 
Studi Perencanaan Pembangkit Listrik Tenaga Sampah Pada TPA Sambutan Kota Samarinda

Tabel 5 Konversi energi gas metana menjadi energi listrik (Soresen, 2007)

\begin{tabular}{cc}
\hline Jenis Energi & :tara Energi \\
\hline $1 \mathrm{Kg}$ Gas Metana & $5,13 \times 10^{7} \mathrm{~J}$ \\
$1 \mathrm{kWh}$ & $3,6 \times 10^{6} \mathrm{~J}$ \\
$1 \mathrm{~m}^{3}$ Gas Metana & $9,39 \mathrm{kWh}$ \\
\hline
\end{tabular}

Setelah diperoleh data-data yang diperlukan maka dilakukan perhitungan menggunakan persamaan 1 Berikut adalah salah satu perhitungan estimasi potensi energi energi listrik pada tahun 2019 :

$$
\begin{aligned}
E & =\text { Gas Metana } \times \text { Faktor Konversi }(k W h) \\
E & =52.675,155 \times 9,39 \mathrm{kWh} \\
& =494.619,705 \mathrm{kWh}
\end{aligned}
$$

Setelah dilakukannya perhitungan, hasil perhitungan energy listrik dari thun 2015-2034 tertera pada Tabel 6.

Tabel 6. Potensi energi listrik

\begin{tabular}{ccc}
\hline Tahun & E $(\mathbf{k W h})$ & Watt \\
\hline 2015 & 225961.3012 & $25.759,58834$ \\
2016 & 1144846.595 & $130.512,5118$ \\
2017 & 1624734.028 & $185.219,6791$ \\
2018 & 2372779.453 & $270.496,8577$ \\
2019 & 2822107.61 & $321.720,2675$ \\
2020 & 3232500.967 & $368.505,1102$ \\
2021 & 3610921.536 & $411.645,0551$ \\
2022 & 3963313.317 & $451.817,7181$ \\
2023 & 4294758.11 & $489.602,4245$ \\
2024 & 4609607.734 & $525.495,2817$ \\
2025 & 4911596.248 & $559.921,9723$ \\
2026 & 5203935.191 & $593.248,6118$ \\
2027 & 5489394.438 & $625.790,9659$ \\
2028 & 5770370.845 & $657.822,2763$ \\
2029 & 6048946.538 & $689.579,9053$ \\
2030 & 6375674.336 & $726.826,8743$ \\
2031 & 6647282.938 & $757.790,2549$ \\
2032 & $6.922 .429,37$ & $789.156,9482$ \\
2033 & $7.202 .192,817$ & $821.049,9811$ \\
2034 & $7.487 .547,11$ & $853.580,3705$ \\
\hline
\end{tabular}

Tabel 6 menunjukan bahwa peningkatan energi listrik dari tahun ke tahun terus mengalami peningkatan, hal ini dikarenakan jumlah timbulan sampah pada TPA Sambutan terus mengalami peningkatan. Tahun 2019 jumlah energi listrik yang dihasilkan ialah sebesar 2.822.107,6 kWh, nilai energi listrik yang dihasilkan sangat memungkinan untuk dibangunnya pembangkit listrik tenaga sampah pada TPA Sambutan Kota Samarinda. 


\subsection{Biaya Investasi}

Biaya investasi meliputi investasi modal tetap dan modal kerja. Investasi modal tetap mencakup perkiraan beberapa komponen biaya langsung seperti biaya pembelian peralatan, utulitas, dan biaya tak langsung seperti biaya perancangan, biaya pengawasan, dan biaya tak terduga. Dalam melakukan asumsi-asumsi untuk biaya investasi di sesuaikan dengan kondisi dan keadaan yang ada di TPA Sambutan.

Menurut data yang diperolah penulis, TPA Sambutan sudah terdapat sistem pengolahan air lindi, yang berupa pipa air lindi, dan juga tempat pengolahan air lindi. Sehingga, biaya-biaya investasi yang terkait dengan hal-hal tersebut tidak lagi diperhitungkan. Sedangkan, harga biaya diperoleh berdasarkan pada LFG Energi Project Development Handbook EPA, 2010 dan dari informasi yang didapatkan dari pihak TPA Sambutan.

Tabel 7. Biaya Investasi

\begin{tabular}{ccccc}
\hline Nama Komponen & Jumlah & Satuan & Harga (Rp) & Total Harga (Rp) \\
\hline Collecton Sistem & 6 & Arce & 34.332 .000 & 205.992 .000 \\
Sistem & 1 & Unit & 1.548 .864 & 1.548 .864 \\
Kondensator & 6 & Unit & 15.041 .000 & 90.246 .000 \\
$\quad$ Blower & 2 & Unit & 11.911 .543 .053 & 23.823 .086 .110 \\
Gas Egine dan & Instalasi & $m^{2}$ & 71.525 & 1.823 .690 \\
Capping dan Instalasi & 25.884 & & & \\
Kabel ACSR & 10.000 & $\mathrm{~m}$ & 100.000 & 1.000 .000 .000 \\
Transformator & 2 & Unit & 30.000 .000 & 60.000 .000 \\
\hline Total & & & & $\mathbf{2 5 . 5 1 8 . 2 6 9 . 6 0 1}$ \\
\hline
\end{tabular}

3.7. Biaya Operasional dan perawatan

Biaya operasional dan perawatan adalah pengeluaran yang diperlukan agar kegiatan operasi dan produksi berjalan dengan lancar dan tidak ada hambatan baik dari segi mesin maupun faktor-faktor lainnya. Biaya ini meliputi biaya tenaga kerja, utilitas, pemeliharaan, dll. perhitungan biaya operasional dan pemeliharaan ini sesuai dengan asumsi diperoleh berdasarkan pada LFG Energi Project Development Handbook EPA, 2010.

Tabel 8 Biaya Operasional dan Perawatan

\begin{tabular}{ccccc}
\hline Nama Komponen & Jumlah & Satuan & Harga $(\mathbf{R p )}$ & Total Harga (Rp) \\
\hline Sumur Gas & 6 & Unit & 22.972 .844 & 137.837 .064 \\
Flare & 1 & Unit & 45.945 .689 & 45.945 .689 \\
Blower & - & Cfm & 454.351 .817 & 454.351 .817 \\
Gas engine & - & $\mathrm{kW}$ & 1.114 .948 .640 & 1.114 .948 .640 \\
Operator dan staff & 4 & Orang & $2.868 .082,58$ & $11.472 .330,30$ \\
maintenance & & & & $\mathbf{1 . 7 6 4 . 5 5 5 . 5 4 0}$ \\
\hline Total (Rp) & & &
\end{tabular}

3.8. Perkiraan Penerimaan Biaya

Besarnya perhitungan penerimaan dengan asumsi bahwa tenaga listrik yang dapat disalurkan adalah $100 \%$ dari daya yang akan dijual. Dengan merujuk kepada Peraturan Menteri Energi dan Sumber Daya mineral (ESDM) Nomor 19 Tahun 2013 tentang Pembelian Tenaga Listrik Oleh PT. Perusahaan Listrik Negara (Persero) Dari Pembangkit Listrik Berbasis Sampah Kota, dimana disitu disebutkan bahwa PT. PLN (Persero) wajib membeli listrik dari TPA dengan pengelolaan sanitary landfill sebesar Rp. $1.250 / \mathrm{kWh}$ (untuk tegangan menengah) dan Rp. 1.598/kWh (untuk tegangan rendah) jika terinterkoneksi dengan jaringan PT. PLN. Maka estimasi besar penerimaan pada tahun pertama adalah sebesar: 


$$
\begin{aligned}
\text { Penerimaan }= & R p .1 .598 \times 520,346 \times 8760 \\
& =R p .7 .284 .053 .070
\end{aligned}
$$

\subsection{Perkiraan Depresiasi}

Umur ekonomis dari pembangkitan potensi energi yang ada pada sampah TPA Sambutan Kota Samarinda jika dibangun dalam bentuk suatu Pembangkit Listrik Tenaga Sampah (PLTSa) diprediksi sekitar 15 tahun. Pada akhir umur pembangkit diprediksi juga masih ada nilai residu dari peralatan dan bangunan tersebut tersisa sekitar 10\% dari harga perolehannya Maka jika dihitung diperoleh nilai residu sebesar:

$$
\begin{gathered}
\text { Residu }=10 \% \times \text { Penerimaan } \\
=10 \% \times R p .7 .284 .053 .070 \\
=R p .728 .405 .307
\end{gathered}
$$

Sehingga didapatkan hasil nilai penyusutan sebesar:

$$
\begin{aligned}
\text { Penyusutan }= & \frac{\text { Penerimaan }- \text { Residu }}{15 \text { Tahun }} \\
& =\frac{R p \cdot 7.284 .053 .070-\text { Rp. } 728.405 .307}{15 \text { Tahun }} \\
& =R p \cdot 655.654 .770
\end{aligned}
$$

3.10. Penilaian Investasi

Penyusunan cash flow menggunakan beberapa asumsi diantaranta adalah discount rate $=15 \%$, discount factor $=25 \%$, umur ekonomiis pembangkit $=15$ Tahun, dan load factor $=0.65 \%$.

a. $\quad$ Net Present Value (NPV)

Dengan menggunkan persamaan 5 NPV dapat di hitung sebagai berikut :

$$
\begin{aligned}
N V P= & \sum_{i=1}^{n} B_{i}-C_{i} \\
N V P= & \left(\frac{R p \cdot 7.284 .053 .070}{(1+15 \%)^{1}}+\frac{R p .7 .284 .053 .070}{(1+15 \%)^{2}} \ldots+\frac{R p .7 .284 .053 .070}{(1+15 \%)^{15}}\right) \\
& \quad-R p .25 .092 .450 .601 \\
& =R p .42 .632 .319 .200-R p .25 .092 .450 .601 \\
& =R p .17 .539 .868 .600
\end{aligned}
$$

b. Internal Rate of Return (IRR)

Besar IRR dapat diperoleh dengan beberapa asumsi dimana nilai $i_{1}$ diasumsikan sebesar $18 \%$ dan $i_{2}$ sebesar $20 \%$, dengan melalukan perhitungan aliran kas yang telah terlampir pada lampiran, maka diperoleh nilai $N P V_{1}=4.039 .914 .978$ dan nilai $N P V_{2}=-1.794 .394 .154$ Dengan menggunakan persamaan 6 maka nilai IRR adalah :

$$
\begin{aligned}
& I R R=i_{1}+\left(\frac{N V P_{1}}{N V P_{1}-N V P_{2}}\right) \times\left(i_{1}+i_{2}\right) \\
& I R R=0.18 \times \frac{4.039 .914 .978}{(4.039 .914 .978-(-1.794 .394 .154))} \times(0.20+1.8) \\
& =0.19 \text { atau } 19 \%
\end{aligned}
$$

c. Benefit Cost Ratio (BCR)

Dengan menggunakan persamaan 7 nilai BCR dapat dihitung sebagai berikut : 


$$
\begin{aligned}
B C R & =\frac{\sum_{K=0}^{N} B_{K}}{\sum_{K=0}^{N} C_{K}} \\
B C R & =\frac{\frac{7.284 .053 .070}{(1+0.15)}+\frac{7.284 .053 .070}{(1+0.15)^{2}}+\cdots+\frac{7.284 .053 .070}{(1+0.15)^{15}}}{24.092 .450 .60} \\
& =\frac{R p, 41.957 .607 .118}{R p .25 .092 .450 .601} \\
& =1.672
\end{aligned}
$$

d. Payback Periode (PP)

Dengan menggunakan persamaan 8 maka nilai PP dapat dihitung sebagai berikut :

$$
\begin{aligned}
P P & =\frac{\text { BiayaInvestasi }}{\text { AnnualCIF }} \\
P P & =\frac{R p \cdot 25.092 .450 .601}{R p \cdot 7.284 .053 .070} \\
& =3.4 \text { Tahun }
\end{aligned}
$$

Tabel 9 Hasil Evaluasi Perencanaan PLTSa TPA Sambutan

\begin{tabular}{cccc}
\hline No & $\begin{array}{c}\text { Parameter } \\
\text { Evaluasi }\end{array}$ & Hasil Perhitungan & Kriteria Kelayakan Proyek \\
\hline 1 & NPV & $R p .17 .539 .868 .600$ & NPV $>0$ \\
2 & PP & 3,4 Tahun & PB $<$ umur ekonomis proyek \\
3 & BCR & 1.672 & BCR $>0$ \\
4 & IRR & $19 \%$ & IRR $>0$ \\
\hline
\end{tabular}

Pada Tabel 9 terlihat bahwa nilai NPV sebesar $R p .17 .539 .868 .600$ yang lebih dari 0 (nol), nilai PB sebesar 3,4 tahun yang dimana nilai tersebut kurang dari umur ekonomis PLTSa yaitu sebesar 15 tahun, nilai BCR yaitu 1.672 yang bernilai lebih dari 0 (nol) menunjukkan perbandingan antara nilai biaya dan manfaat jika nilai BCR lebih dari 0 (nol) maka keuntungan yang diperoleh melebihi biaya pembangunan, dan nilai IRR adalah sebesar $19 \%$ dimana IRR adalah besarnya tingkat keuntungan yang digunakan untuk melunasi jumlah uang yang dipinjam agar tercapai keseimbangan. Dari Tabel 9 dapat dikatakan bahwa perencanaan PLTSa layak dibangun karena dari analisis ekonomi yang telah dijabarkan dan tertera pada Tabel 9 semua parameter evaluasi memenuhi kelayakan suatu proyek.

\section{Kesimpulan}

Berdasarkan studi perencanaan PLTSa pada TPA Sambutan, Kota Samarinda, dapat disimpulkan bahwa Gas landfill yang dihasilkan pada TPA Sambutan Kota Samarinda mencapai nilai $684.693,866 \mathrm{~m}^{3}$ pada tahun 2019 dan akan meningkat setiap tahunnya sampai dengan tahun 2034. Berdasarkan potensi sampah yang terestimasi dapat dihiung potensi energi listrik yang dihasilkan pada TPA Sambutan sebesar 2.822.107,61 $\mathrm{kWh}$ pada tahun 2019 dan meningkat sampai dengan tahun 2034. Untuk mengimplemetasikan PLTSa komponen electrical yang digunakan pada PLTSa TPA Sambutan Kota Samarinda adalah gas engine model Janbacher J 320 GS berkapasitas 1,063 kW 2 buah. Dengan Biaya investasi untuk pembangunan PLTSa yaitu sebesar Rp. 25.518.269.601. Dan Hasil evaluasi investasi $\mathrm{NPV}=\mathrm{Rp} \cdot 17.539 .868 .600, \mathrm{IRR}=19 \%, \mathrm{BCR}=1.672$ dan $\mathrm{PB}=3.4$ Tahun. Semua parameter evaluasi investasi menunjukan hasil yang memenuhi kriteria bahwa PLTSa TPA Sambutan layak untuk dibangun.

\section{Daftar Pustaka}


Abdul Muiz Liddinillajj Sanfiyan, Yuri ArdiansyahAmin, Eka Maulana (2017). "Perancangan Pembangkit Listrik Tenaga Sampah Organik Zero Waste Di Kabupaten Tegal (Studi Kasus Di TPA Penujah Kabupaten Tegal)”. Volume.6 No.4. Jurnal Teknik Mesin.Universitas Pancasila Jakarta, Jakarta.

Agung Tri Prasetiyo, Didik Notosoedjono, Waryani (2017). "Studi Evaluasi Pembangkit Listrik Tenaga Sampah Di Tempat Pengolahan Sampah Terpadu Bantargebang”.Universitas Pakuan Bogor.

Amelya Pratiwi Indah, Farman Ali (2015). "Analisis Kelayakan Pembangunan Pembangkit Listrik Tenaga Biogas Di TPA Tamangapa Makassar”. Gorontalo.Universitas Ichsan Gorontalo.

Archie W. Culp, Prinsip-Prinsip Konversi Energi, Jakarta: Erlangga, 1998.

Artiningsih, Ni Komang Ayu. (2008). Peran Serta Masyarakat dalam Pengelolaan Sampah Rumah Tangga. Semarang : UNDIP Press

BAPPEDA Kota Samarinda.(2015). "Rencana Pembangunan Jangka Panjang Daerah KOTA SAMARINDA Tahun 2005 - 2025".Kota Samarinda.

Bent Sorensen . (2007). "Renewable Energy Conversion, Transmission, And Storage". California.

Faizah,(2008), Pengelolaan Sampah Rumah Tangga Berbasis Masyarakat (Studi Kasus di Kota Yogyakarta). Semarang: Skripsi pada Universitas Diponegoro.

Hadiwiyoto, S. (1983). Penanganan dan Pemanfaatan Sampah. Jakarta : Yayasan Idayu Press.

Ismoyo, Imam Hendargo. (1994). Kamus Kesehatan Lingkungan. Jakarta : PT Bina Rena Pariwara.

La Ode Mohammad, Sugeng Haryono, Wibowo Prayatmo (2015). "Studi Potensi Dan Pemanfaatan Sampah Padat Perkotaan Untuk Pembangkit Listrik Di TPA Penujah Kabupaten Tegal". Volume.5 No.3. Jurnal Ilmiah TEKNOBIZ

Nazlie Haq. Alan (2012). "Studi Potensi pembangunan Pembangkit Listrik Tenaga Sampah di Kota Banjarmasin". Universitas Diponegoro. Semarang.

Nofri Dodi, Syafii, Slamet Raharjo (2015). "Studi Kajian Kelayakan Pembangunan Pembangkit Listrik Tenaga Sampah (Pltsa) Kota Padang (Studi Kajian Di Tpa Air Dingin Kota Padang)".Volune 4 No.2. Jurnal Teknik Elektro ITP.

Rachmad Ikhsan, Syukriyadin (2014). "Studi Kelayakan Pembangunan Pembangkit Listrik Tenaga Sampah (PLTSa) di TPA Kota Banda Aceh:. ISSN :2088-9984. Seminar Nasional dan Expo Teknik Elektro.

S. Mannfredi, D. Tonini, and T. H. Christensen, (2009), "Landfilling of Waste: Accounting of Greenhouse Gases And Global Warming Contributions," Journal of Urban Climate, March, pp. $825-836$.

Sulasno,(2009), Teknik Konversi Energi Listrik dan Sistem Pengaturan, Yogyakarta: PT.Graha Ilmu,. Syarifudin,(2011), "Analisis Manfaat Dan Biaya Pembangkit Listrik Tenaga Sampah Untuk Desa Terpencil Di Indragiri Hilir (Studi Kasus: TPA Sambutan", Jurusan Teknik Elektro., Universitas Indonesia., Depok,

Tchobanoglous, G. (1993). Integrated Solid Waste Management Engineering Principles and Management Issues. New York : McGraw-Hill

V. P. Garcilasso, S. M. S. G. Velázquez, S. T. Coelho, and L. S. Silva, (2011). "Electric energi generation from landfill biogas - Case study and barriers," Int. Conf. Electr. Control Eng. ICECE 2011 - Proc., pp. 5250-5253. 2011. 